\title{
THE USE OF POETRY IN A SPIRAL-PATTERNED METHODOLOGY FOR RESEARCH ABOUT LOVE IN EARLY CHILDHOOD
}

\section{The author}

Sarah Cousins is a Director of Early Years Programmes in the Centre for Lifelong Learning at the University of Warwick. She has extensive experience as an Early Years teacher, leader, consultant, inspector and lecturer. She engages in interdisciplinary research about affective aspects of care work.

\section{$\underline{\text { S.Cousins.1@warwick.ac.uk }}$}

\section{Introduction}

In this paper I suggest that the use of poetry within a slow, spiral-patterned methodological approach is appropriate for research about people's complex lives. The concept of a spiral pattern serves to mirror the process I adopted to make meaning from qualitative data. It is a slow, recursive technique for analysing multi-faceted data with "thick descriptions" (Taggart et al, 2015, p25). The pattern is represented in Figure 1 with details of research activities in Figure 2.

The context for this paper is research about the importance of 'love' in Early Childhood Education and Care (ECEC). The research in question was carried out in five contrasting settings in London. I learned, through a series of research activities, including poetry writing, that early years practitioners bring so much more to their work than that which they learned from their professional training or work experience. In other words, they learn in an integrated way, from multiple sources. This points to the need for practitioners to move away from an either-or paradigm, where knowledge is gained either formally or informally, in professional or wider life contexts, to a more blended approach of "intertwined" knowing (Martin and Kamberelis, 2013, p.672). Within such a paradigm, practitioners acquire knowledge from research and scholarship as well as from their own personal, life learning, and this in turn enriches the work they do. This research found that 
practitioners apply their life learning, ingrained in their bodies (Bourdieu, 1997), to their work with young children and families, and build 'landscapes of love' in their workplaces.

This notion of 'landscapes' was applied to educational contexts by Clandinin and Connelly (1996). They wrote about professional knowledge landscapes, and conceived of this as the interface between theory and practice in professional lives. This research draws on their metaphor. It proposes that early years practitioners bring their own cultural and familial understanding of love to their diverse work contexts and skillfully convert this into 'professional love' (Page, 2011, 2013). The work they do is highly complex. The research points to the need for appropriate support for this emotional, physical and intellectual work. Love, the research celebrated, is on offer in diverse ways. This paper presents the research process.

\section{Why the topic is important}

In this section I offer my rationale for taking up this topic of love, firstly, based on my interests and experiences, and, secondly, based on my review of the literature related to the topic. Love in the context of ECEC matters to me very much. As an early years teacher I became aware of the importance of love in the context of my work. I believed I made a difference to the children in my Nursery or Receptions classes (ages 3-5), and that this was due less because I was diligent or hard working, applied specific strategies to support the children's learning and development, or followed particular pedagogic principles, but more as a consequence of love. I devoted my talents, time, emotions and energy to my work, and as each academic year progressed, I grew to love the children in my class. By the end of the year we became like a family, and it was difficult to say goodbye. This is the aspect of my own experience that sparked my interest in the topic and prompted me to research it.

Love has also been the focus of some research studies (Goldstein, 1997, Goldstein, 1998, Page, 2012). Goldstein was motivated to research love based on her own experience as a teacher. She acknowledged although affective matters were problematic and difficult to research in some ways, "the affective won't go away" (p.30). She reflected on what she called "teacherlove" (Goldstein, 1997, p.121) over a period of time, and found that it did not differ in intensity to love in family contexts. It was only more limited by time. Goldstein used observations and personal reflections to explore the meaning of love. For example, she found that love for children was different to feeling warm or positive towards them. The notion of 
teacherlove encapsulated a passion for learning and teaching. Page (2012) carried out research with mothers and found that they wanted their children to be loved while they were in the care of professionals. Love-related matters, such as emotions, attachments and care, are widely referred to in the research literature (Elfer, Goldshmeid and Selleck, 2012, Osgood, 2012, Lynch, Baker and Lyons, 2009). However, there is also a gap in the research literature related to the topic of love in ECEC. While Page $(2010,2011,2013)$ carried out research about love with mothers and Osgood $(2010,2011,2012)$ carried out research about early years professionalism with practitioners, no researchers had previously sought early years practitioners' constructions of love in the context of their work in ECEC settings. This research sought to find out how practitioners construct love in ECEC.

\section{A spiral-patterned research methodology}

In the research about love in Early Childhood Education and Care I interwove poetry with prose, narrative sections with academic text, personal reflections with the reflections about other people. This supported me, as articulated by Halley (2002), to "explore a nonlinear, repetitive kind of knowing and speaking the world" (p.91). The research adopted a spiral-patterned methodological approach, similar to de Carteret's (2008) notion of "the spiral of ideas" (p.241), whereby I re-visited the narratives, returned to the participants, wrote research journal entries in a blog, composed poems based on the narratives, thought about the narratives, carried out a thematic analysis (Braun and Clarke, 2006), and so on in a spiral pattern. This recursive research pattern allowed me to say things more than once in different ways to support my own understanding and the development of a thesis.

This spiral-patterned approach allowed me time to think as I developed my interpretations of the narratives. At the early stages of reflecting on the transcripts, for example, I felt certain that the notion of 'landscape' was both a physical and figurative one. In the first four stories I reflected on, the physical and outdoor landscapes featured prominently as a recurring backdrop for moments of contented-ness and development in each of the participants' lives. 'Contented-ness', in this context, is akin to the notion of 'wellbeing', whereby, in Elfer et al's (2012) terms, children feel valued, acknowledged for who they are and special. In four of these stories, a sense of well-being appeared to be associated with experiences in communal, wider-family or neighbourhood spaces. 
It was not until I turned to the final story in my cycle of research encounters, that this link, which I perceived as important, was broken. This notion of landscapes in the geographical sense was lost and the maps I conceived of became less rooted in place, not geography, and more connected to the notion of 'habitus', in Bourdieu's sense of the word. 'Habitus', according to Bourdieu (1991), refers to "a set of dispositions which incline agents to act and react in certain ways" (p.12).

The participants talked about their childhood experiences of love, and how this played out in their work with children. People's dispositions, or innate beliefs, suggests Bourdieu, lie at the heart of their actions, are known unconsciously, are reliable, enduring, regular. 'Habitus' is an important concept in these discussions in that each participant appears to have developed a unique landscape in their professional work-spaces that, I propose, is built, in part, with reference to their unique "set of dispositions" (Bourdieu, 1991, p.12) acquired through their life-long learning. The slow, recursive, spiral-patterned approach, with time for additional reading, supported me to make this connection with Bourdieu's theory. The unhurried thinking time between the different research activities helped me make links between the data and different areas of knowledge. With reference to Bourdieu's theory of habitus, I thought of the participants as people-practitioners who, consciously and unconsciously, drew on their life-learning as people in their work as professionals. In other words, the participants applied their learned dispositions, or ways of being, to their professional work with children and families.

I adopted a creative and personalised process. The process, which I conceptualised as a spiral-patterned one, followed a recursive and multi-layered pathway, as depicted in Figure 1 below. In Figure 2, I offer further elaborations on each of the staged activities. 


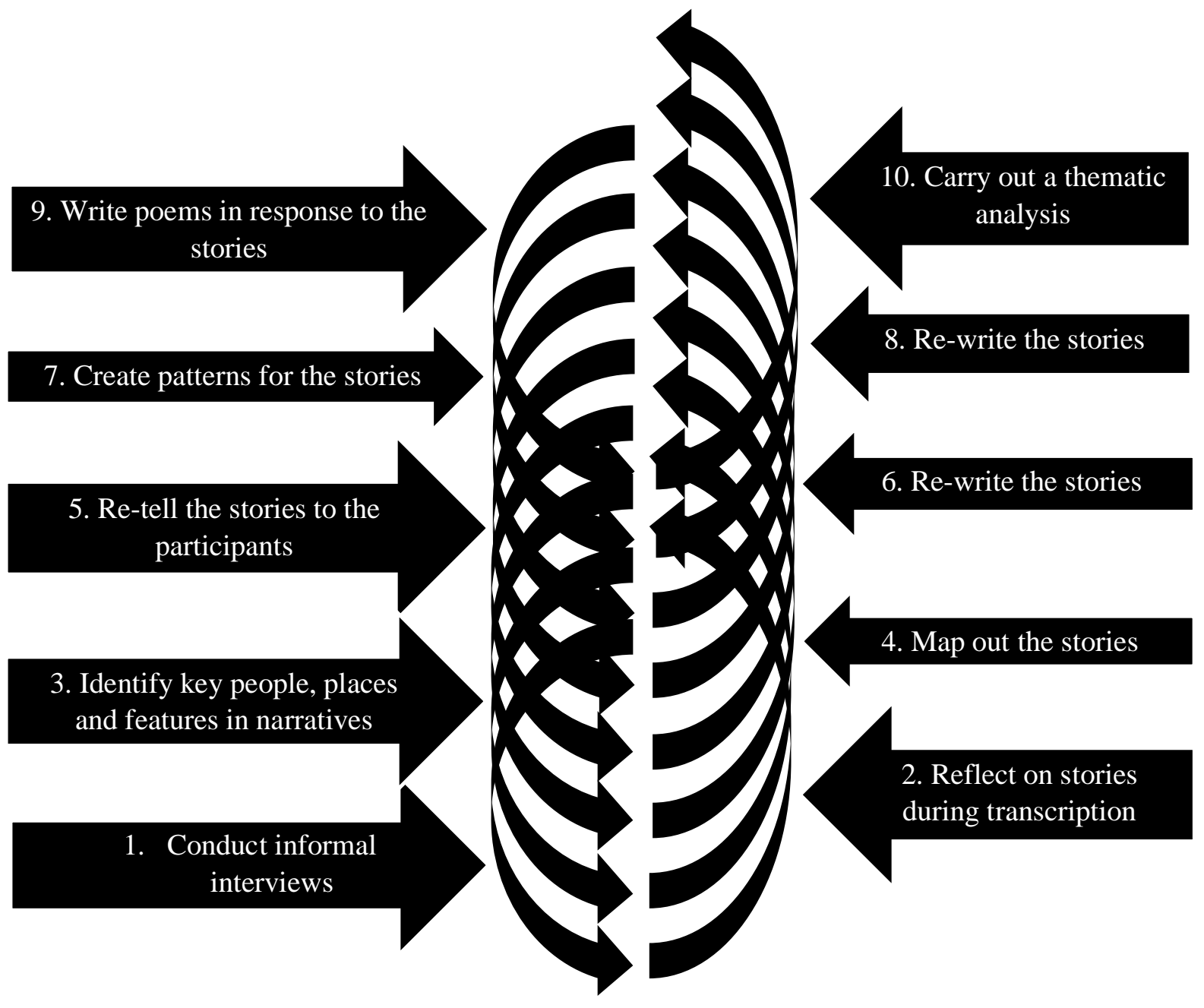

Figure 1: Spiral-patterned methodology 


\section{Spiral-patterned methodology \\ (Further details)}

\begin{tabular}{|c|c|}
\hline Activity & My role \\
\hline $\begin{array}{l}\text { 1. Conduct } \\
\text { informal } \\
\text { interviews } \\
\text { (narrative } \\
\text { sessions) }\end{array}$ & $\begin{array}{l}\text { - Offer a generative narrative prompt (Flick 2009) to stimulate discussions } \\
\text { - } \quad \text { Record interviews } \\
\text { - Maintain an attentive pose, acknowledging all contributions } \\
\text { - Offer further prompts as necessary }\end{array}$ \\
\hline $\begin{array}{l}\text { 2. Reflect on } \\
\text { stories } \\
\text { during } \\
\text { transcription }\end{array}$ & $\begin{array}{l}\text { - Listen to the recordings, stopping, rewinding and replaying them until I capture } \\
\text { the narratives verbatim } \\
\text { - Re-experience the interviews through this transcription phase }\end{array}$ \\
\hline $\begin{array}{l}\text { 3. Identify } \\
\text { key people, } \\
\text { locations and } \\
\text { features }\end{array}$ & $\begin{array}{l}\text { - Re-read the transcripts, identifying key people (e.g. family members), locations } \\
\text { (e.g. home, school, other places) and features (e.g. outdoor experiences) in the } \\
\text { narratives } \\
\text { - Prepare a set of cards to represent the above for each narrative }\end{array}$ \\
\hline $\begin{array}{l}\text { 4. Map out } \\
\text { the stories }\end{array}$ & $\begin{array}{l}\text { - Obtain maps of the actual geographical places referred to (not appropriate in } \\
\text { Kathleen's story) } \\
\text { - Place the cards onto the maps to develop story maps (e.g. Angela often took the } \\
\text { train from her home in London to a particular heath in outer London where she } \\
\text { went fishing with her sister, parents and "Auntie") }\end{array}$ \\
\hline $\begin{array}{l}\text { 5. Re-tell the } \\
\text { stories to the } \\
\text { participants }\end{array}$ & $\begin{array}{l}\text { - Re-tell the stories to the participants placing the appropriate set of cards on the } \\
\text { floor (without the actual maps as a backdrop since these were used to help me } \\
\text { organise the lay-out of each story map at an earlier stage) } \\
\text { - Write any new details offered on further cards and place these on the story map } \\
\text { - Take picture of card array }\end{array}$ \\
\hline $\begin{array}{l}\text { 6. Re-write } \\
\text { the stories }\end{array}$ & $\begin{array}{l}\text { - Re-shape the narratives into stories, or "narrative accounts" (Barrett 2009, } \\
\text { p.121) } \\
\text { Rationale: To deepen my knowledge and understanding of the stories through the } \\
\text { activity of writing } \\
\text { - Seek consent from the participants to include my own versions of their stories in } \\
\text { the thesis } \\
\text { - Reflect on all the stories }\end{array}$ \\
\hline $\begin{array}{l}\text { 7. Create } \\
\text { patterns for } \\
\text { the stories }\end{array}$ & $\begin{array}{l}\text { - Re-create story maps at home } \\
\text { - Reflect on the stories } \\
\text { - Create plans to represent the patterns (as I perceived the) in some of the stories, } \\
\text { e.g. Hilary's }\end{array}$ \\
\hline $\begin{array}{l}\text { 8. Re-write } \\
\text { the stories }\end{array}$ & $\begin{array}{l}\text { Transform the transcripts into short stories through a process of reflection, } \\
\text { writing, reading aloud, editing and re-writing }\end{array}$ \\
\hline $\begin{array}{l}\text { 9. Write } \\
\text { poems for } \\
\text { the stories }\end{array}$ & $\begin{array}{l}\text { - Write poems to represent some of the content of the stories or to express the } \\
\text { stories differently and more succinctly } \\
\text { - Rationale: To reflect on the stories more freely, focusing on resonating sections } \\
\text { and unconstrained by linear structures }\end{array}$ \\
\hline $\begin{array}{l}\text { 10. Carry out } \\
\text { thematic } \\
\text { analysis }\end{array}$ & $\begin{array}{l}\text { - } \text { Consider more closely what the participants said in relation to each theme } \\
\text { - Make links with literature } \\
\text { - Identify themes that do not occur in literature }\end{array}$ \\
\hline
\end{tabular}

Figure 2 
At an early stage on the pathway I elicited the interviews one after the other within a fairly short period of time. I reminded the participants about my research interest in the topic of 'love' and invited them to talk about how they understood it in the context of their work. At the next interpretive layer I reflected on the stories as I transcribed them while becoming acquainted with the new stories I elicit. My knowledge was cumulative and my interpretations were coloured each time by my newly acquired knowledge. Sometimes I stepped away from the process, read more, wrote a short, disembedded blog entry to develop my thoughts before returning to the spiral-patterned process. These pauses, as I conceived them, represent resting and refuelling points, like oases, on the reflective, interpretive process.

At the next layer I reflected on the interview narratives again, identifying distinctive features, including significant people such as close family members, specific places such as the name of a London area, and themes, such as the recurring theme of 'outdoors'. I prepared a set of concept cards to capture my interpretations for each story. At the next reflective layer I returned to the participants and re-told them their stories as I perceived them, placing the concept cards in an array to develop a story map. At this stage the participants confirmed my interpretations of the stories, provided additional details and made adjustments, as necessary. This mapping process allowed me to organise the content of each story till it made sense and produced new understanding. This was part of my analytical, or sense-making toolkit. As Martin and Kamberelis (2012) propose, "mapping discloses potential organisations of reality rather than reproducing some prior organization of it" (p.671). This mapping activity, then, allowed me to create new meaning rather than simply trace or replicate the stories, and allowed the notion of 'landscapes of love' to "come about" (Deleuze and Guattari, 1994, p.111), emerge as "a becoming" (Deleuze and Guattari, 1988, 347).

After the mapping I reconsidered the interview narratives in light of the new information, personal responses from participants, my own emotional responses to all the stories, the ideas that came about through the mapping. At this interpretive layer I re-wrote these in my own words, and this allowed further poems to "come about". At a later stage, I carried out a thematic analysis of the interview transcripts.

This multi-layered, cumulative approach allowed me time to re-visit and re-consider the stories at different phases of the spiral-patterned research process. At each new phase, I incorporated further layers of my own accumulated insights gained through the reflective 
process. The time gap between my two visits to the participants, I suggest, allowed my participants and me time to think about the research and re-visit the narratives together. The participants welcomed the second visit, I sensed, and appeared interested to hear my version of their own story, offering frequent affirmations in relation to the content and providing further details as necessary. Importantly, I suggest, this aspect of the research process offered the opportunity for us to build up bonds of trust with each other, thereby facilitating the story-telling process and allowing the stories to "take shape" (Caine and Estefan, 2011).

Page (2013) emphasised the value of adopting slow, recursive approaches for research about love in ECEC. She argued that her "four-staged process of meaning-making" (p.10) allowed her to move forward from the "rawness" (p.10) of people's narratives to establish a critical, analytical approach. Such an approach is, I suggest, appropriate in the field of ECEC especially in relation to affective matters such as love. It offers participants and researchers time for thinking and opportunities for adding further layers to the research process, as necessary,

My 'spiral-patterned' image evokes this repetitive motion, with layers for perceiving the stories again and again, and each time from a new position on the conceptual spiral. The poetry represents an important layer on the spiral journey. As my understanding of the interview narratives deepened I was sometimes moved to encapsulate my response to them in a poem. I arrived at insights and made recommendations, but, in accordance with my relativist stance, these were only ever considered partial (Richardson, 1990, Richardson and St Pierre, 2008, Denzin, 2008), context specific, personal, with more to be said. As Clandinin and Rosiek (2007) proposed, experience in the world always represents "more than we can know and represent" (p.39). I focused in on these constructions of love with my personal lenses and the best I could do was declare this as a biased perspective (Bruner, 1990). There is, I held, much more to be said and innumerable other stories to be told.

This 'spiral-patterned' research process, with distinct places and times for "dwelling" (Phipps and Saunders, 2009, p.361, Barone, 2001, p.25) along the way, I suggest, is in tune with this narrative and poetic inquiry. Individual stories were at the heart of this research process. The process also contained elements of arts-based inquiry (Barone, 2001, Lapum et al, 2011, Bagley and Castro-Salazar, 2012) with the poems themselves serving to convey the messages of the research in a different way, thereby adding a further mode of communication. This approach has synergies too with ethnomethodology in that it shares an 
emphasis on deep study of a profession or activity, and there is a conscious avoidance of any rigid methods that may "impose a priori or extrinsic definitions of pattern and order" (Pollner and Emerson, 2001, p.119). The pattern is defined by the narratives and the participants who constructed them.

Clandinin and Rosiek (2007) emphasised the importance of developing an approach over time to match the particular circumstances of the research. An "honest empirical method" (p.40), they suggested, consists of "a series of choices ... undertaken through time" (Clandinin and Rosiek 2007, p.40). Page (2013) unpacked the intricate details and multiple dilemmas contained in such a painstaking process, and proposed that such an approach is necessary in order to be a "responsible researcher and ... responsible storyteller" (p.23). Time, I concur with these authors, allowed me space in which to reflect carefully on the stories, consider what was the responsible thing to do at each stage, plan my next steps, read more, write. Accordingly, this is something that I will take forward in my work as an educational researcher.

\section{What the participants said about love}

I selected five participants from a range of ECEC settings. All of the participants were female. This was not a planned decision, but simply arose since the majority of the people I was in close contact with in the early years sector during the research planning period were female. Additionally, and as Boyer, Reimer and Irvine (2012) pointed out in relation to their own predominantly female sample, the sample was a good reflection of the “(largely) female" (p.519) sector as a whole.

The five female participants I chose were located in five contrasting settings:

1. A private nursery, part of a nursery chain of five in a particular London locality

2. A large Children's Centre, established in the first round of Children's Centres

3. A nursery school attached to a Children's Centre

4. A nursery class attached to a two-form entry Primary School

5. A childminder's home setting

This selection, although not representative of all early years workers, offers diverse examples of working contexts. The different participants worked for individual owners, nursery headteachers or managers, school headteachers or for themselves. They 
worked on their own, in small centres, or as part of room or classroom teams within larger centres of schools.

The participants came from different socio-economic backgrounds and cultural heritages. I sought this personal and professional diversity in order to foreground the importance of personal histories and diverse cultural experiences. I also wanted to choose participants who held different qualifications or had followed different career routes into the profession. This was in order to answer one of my research questions: What do practitioners say about their formal training in relation to loving children in their care?

All five of the participants held managerial or leading practitioner roles in their settings. I made this choice because I wanted to elicit constructions of love from the people who made the decisions about practice or led others to adopt particular approaches. So, although on the one hand I wanted a range of perspectives, I also wanted this range of perspectives to come from people who took a lead on developing practice in their settings. As leaders, these participants would be likely to be involved in shaping policies in their settings and would have ownership of organisational and pedagogic approaches.

Despite numerous synergies between the narratives, the five participants talked about love in very different ways, drawing on their diverse social and cultural resources to do so. Several themes emerged as prominent across the interview narratives. All five participants talked at length about love in ECEC, with very little prompting from me. They said that it was important to love children, because this contributed to their social and emotional development, thus preparing them for the future, helping them to learn to behave, to be ready to move on to school, to grow as people, to gain self-confidence, and to learn.

Another way the participants talked about supporting children's development was by showing love in demonstrative ways, for example, by hugging children. They said this was important for children's healthy emotional development, and to build their self-confidence and sense of self-worth, particularly when they were hurt, upset or in need of reassurance. They suggested that touch was an important element in cultural repertoires of how children are normally treated. They said that to restrict touch was contrary to good practice, and that not touching small children limited their development. Their concern was that they were being required to monitor and limit the ways in which children were touched. They said this went against their instincts both as human beings and professionals. 
The participants also said it was important that those who worked in ECEC settings should be people who could show love for children, and for whom loving children was "natural" and an "innate" quality. One participant said that this natural love was "more so in the female sex", where it was in women "deep somewhere to love children". Two of the participants said that different people showed love in different ways and that children sometimes approach adults with whom they felt "more comfortable".

Overall, the participants constructed love in ECEC settings as different from love within families. The key difference they identified was that children were only in ECEC settings on a temporary basis (both in terms of hours of the day, and also years of their lives). However, they pointed out that parents wanted to know that their children were loved while in the care of professionals, or in non-familial contexts. While clearly distinguishing between love in the family and in a work setting, the participant who worked as a childminder in her own home identified the most similarities between the two, and was explicit that her role let her "be a mum" on a temporary basis.

As well as talking about loving children, four out of five of the participants talked about loving to be with children. This is a rather different use of the word love, focusing on practitioners' own emotions rather than on any potential benefits to the children. Related to this, three participants talked about the importance of practitioners showing children their own emotions.

Three of the participants referred to the idea of practitioners as people who experience ups and downs. Angela talked about being "a bit grumpy sometimes”, and Kathleen said she was "cross" or "tired" on occasions. Hilary said it was important to be honest about her emotions with the children. She said that, even if she were having a bad day, she would not try to hide her own feelings from children.

Hilary: That is an emotion that you have and you have every right to express that emotion and show that emotion, so that when they have that emotion, they know that it's OK to show it and express it.

These participants said that it is good for children to see the people who care for them as ordinary human beings with emotions and weaknesses. Being less than "super people" (Angela), in other words, is " $O K$ ” (Hilary) on occasions. This, they said, was important for children's development, and that children, "do need to see that" (Kathleen). 
All five participants talked about their own experiences of being loved (or not) as children. The interviews about love in the early years triggered this association for all of them. The participants talked about what they did as ECEC practitioners and how they constructed this either with reference to their childhood experiences, or, if necessary, in stark contrast to it.

Kathleen, for example, talked about the "tactile" approach in her family and a sense whereby "we would have known that we were loved". She also said:

And I think that is probably why I am comfortable with it now. I think as you grow up, so you go on to do.

She said that she learned how to love from her family:

I came from that kind of, mmm, home where we were loved, we were hugged, mmm, physically and mentally probably, and I think that is important.

\section{Language for research about love}

The research was couched in my belief that no thing (Richardson 1990), such as a piece of writing, can fully convey the aspects of life that it sets out to represent. As Denzin suggests, "reality in its complexities can never be fully captured" (Denzin, 2010 p.423). Similarly, St Pierre (2013) challenged the notion that "there is a reality out there to be found out and that language can accurately represent it" (p.649). Sikes and Gale (2006), in a similar vein, note that there are no "techniques" (p.14) for relating aspects of life. Complex lives, I hold with these authors, have no single or direct correlation in the words we use to express our experiences.

For Deleuze and Guattari (1994), "concepts have no reference to the lived or states of affairs" (p.144). Indeed, Foucault (1972) had challenged the notion that there was anything beyond language, and as Rorty (1986) wrote in his critique of Foucault's theories, he believed that "we only know the world and ourselves under a description" (p.48). Talk, then, does not refer to real things (Gergen, 1999). Instead, it is how people communicate with others in their communities (Rorty, 1991), construct stories (Burr, 2003) and make meaning (Bochner, 2014). I concur with Rorty $(1982,1986)$ who argues that language evolves with reference to people's needs and desire to express themselves, and is developed out of people's cultural and social circumstances. Language, then, like culture, which, as Williams (1976) 
elaborated, comes from the Latin word cultura, and originally referred to a process of tending crops or animals, grows slowly.

I am drawn to artistic ways of knowing and perceiving things. Poetry does not run the risk of claiming representation of things. Instead it creates new possibilities for thinking about and experiencing the world. This is the work that the poetry does in this research. The poems create something new from the data thereby opening up new possibilities. In the same way, the maps and plans I developed on the research journey supported me to make new connections and view things differently rather than acquire accurate charts or depictions of people's lives.

Hughes (1997), writing about Deleuzian interpretations of fiction emphasises the potential for fiction to act on the reader. Hughes explores Deleuze's notion of 'haeccity' whereby texts act on people, affect them bodily, create new things, allow "an event of becoming" (p.54). In this sense, writing has a "deterritorializing force" (p.75). It places the writer and reader somewhere new. The stories and poems in the research, I suggest, came together for the first time and created the possibility of new connections and ways of perceiving things.

Jackson and Mazzei (2012), too, with reference to Barad's philosophical works, explain how words and the material world "intra-act to enable an encounter with the previously unthought" (p.188). The authors highlight Barad's emphasis on the importance of the material, and how people's very materiality affects how they know things. Words affect people physically and move them to think new things. The material and the discursive, suggest Jackson and Mazzei, are related to each other. Accordingly, I offered the words and sounds of the narratives and poems as ways to reach, touch, affect people, including me as the researcher, in different and new ways.

\section{The philosophic perspective for the research}

The research about love in Early Childhood was couched within my own distrust of firm structures, rigid ways of doing things, a positivist outlook. I am more comfortable with doubt than certainty, questions than answers, heterogeneity than homogeneity, diverse perspectives than single claims to truth. With Richardson and St Pierre (2008), I hold that "having a partial, local and historical knowledge is still knowing" (p.476), and that "we know 
there is always more to know" (p.479). In other words, my human frailty and limitations do not prevent my yearning to know. While I accept that my knowledge is in some ways insignificant, blinkered, situated, my own, these aspects do not stop me from longing for it. I know there is more to learn and that any knowledge I gain will be superseded by other knowledge, but it is nevertheless worth having.

These beliefs, I suggest, have synergies with pragmatism. Pragmatism acknowledges the complexity of living in the world, where nothing is certain and positions are always subjective. The pragmatic researcher in contrast to the positivist one, according to Oliver, Nesbit and Kelly (2013), does not set out to discover once-and-for-all truths, but only to shed light on situated, context-specific ways of being. The pragmatic researcher, these authors suggest, acknowledges the complexity of the world and "the need to capture ever-changing, ambiguous, constructed realities" (p.12).

From these non-positivist stances I adopted and developed "narrative processes" (de Carteret, 2008, p.242). The process of writing was an important action in developing my thinking and helped to shape my interpretation of the interview narratives. With Phipps and Saunders (2009) I view poetry as a "creative companion to, not substitute for, expository discourse" (p.370). The research included "re-presentations" (Sikes and Gale, 2006, Sikes, 2009) of stories, writing as a means of knowing, story maps and poetry. These processes, on a slow, spiral-patterned research trajectory, led to research insights that, I propose, may not have otherwise been gleaned.

\section{Narrative inquiry: a rationale}

Narrative inquiry allowed me to gain insights, perceive things differently, make connections, learn about people's lives and work situations. With Huebner (1999) I believe that language has the power to "open up a world" (p.148). My participants offered me their narratives, which, as Richardson (1990) pointed out, is how they make sense of, or "reconstruct" (p.23), their lives. I then interpreted their narratives, "weigh[ing] and sift[ing]" (Richardson, 1990, p.10) the content, "mak[ing] choices" (p.10) about what to include and foreground. The narratives, then, were the "malleable" stuff of the research. Narrative inquiry, as I experienced it, is a creative process for learning about people. 
The stories in the research about people include details of places, people and current issues. With Richardson (1990), I believe that "narrative is the best way to understand the human experience because it is the way humans understand their lives" (p.65). As Lewis (2011) put forward, "it is through the story that we come to know, through the story of the other” (p.505). Real life, as I experience it, does not necessarily follow a linear pattern nor fit into a conventional story frame. Narrative inquiry, I suggest, is an appropriate approach for matching this human complexity.

\section{Ethical considerations}

Denzin (2008) cautioned that stories in research may sometimes become disembedded narratives for analysis, objects "ripped or torn out of" (p.117) their contexts. Accordingly, I asked myself: Did I snatch my participants' stories from them for the purposes of developing my research? Did my interpretations of the stories match my participants' lived realities? These questions troubled me. To this end I remained in touch with my participants. I revisited them to check that my interpretations of their stories accorded with them, and to elicit further details, as appropriate. This is not to suggest that I sought to verify my research in this way. To suggest this would be to acknowledge that I believe there is one definitive story to tell. I returned to them because, as I understand narrative inquiry, it is "a collaborative venture" (Caine and Estefan, 2011, p.967). I wanted to talk through my emerging thinking with my participants, learn more in conversation with them, experience our "intertwined knowing” (p.976).

At a later stage I sent the participants my "re-presentations" (Sikes, 2009, p.181) of their stories for their further consent. Again, this was not to seek verification, but because I felt this was the ethical thing to do. I wanted to ensure that there was nothing in the versions I wrote that would cause any of my participants to be disturbed or troubled in any way.

Plummer (2001) suggested that great "care must be taken [not to] lose sight of the very documents in their richness and humanity" (p.202) that researchers first sought to learn from. Plummer's consideration was useful to me in the research process, particularly in relation to my decision to reflect and interpret each story separately. I did not want to lose the multiple and unique threads contained in each story, and, like Sikes (2009), I wanted to maintain the uniquely personal aspect of each story. In tune with research by Sikes (2009), I was uneasy about blending the stories into one, or pulling themes and characteristics together, 
since such an approach, I feared, might fail to take account of uniquely personal features and circumstances.

\section{Researcher relationships}

As a narrative inquirer, I was involved with my participants, and together we shaped the research. My participants and I were in contact with each other for over two years during the research period. I met them in their workspaces, shared cups of tea with them, chatted before and after the research, remained in email contact, revisited them, got in touch again to seek further consent. The participants, I sensed, welcomed me. In this sense, I had "an emotional connection" (Caine and Estefan, 2011, p.967) to my participants. Their rich stories, as I perceived them, were shared with me, given to me, remained with me. The relationship I formed with them was unexpected and continuous. I could never have predicted what emerged in the narratives, and I continued to think about them after the research encounters. I was drawn in emotionally to their stories, and these emotions did not terminate when the research was done (Bagley and Castro-Salazar, 2012). As a narrative researcher, I went on a research journey with my participants, and shared conversations, insights and understandings with them (Ceglowski, 2002), some of which "touch[ed]" (Caine and Estefan, 2011, p.968) me deeply. One of the participants spoke of her hatred for her father, another about her pain when the children in her care leave her, and another about her sense of isolation as a child. In these instances, I was affected, physically struck.

With Caine and Estefan, I go so far as to suggest that "relationships are at the heart of narrative inquiry" (p.969), and that it is through these relationships that "stories emerge onto research landscapes" (p.969) and shape how people think and feel. These relationships, which may continue in the hearts and minds of participants and researchers after the research is complete, form and feed narrative inquiry. As Ceglowski (2002) reflects, "I enter the lived experience of those I study" (p.6) and allow their lives to affect me physically, or "get under my skin" (p.15). Stories, in my experience as a researcher, are shaped in dynamic, human, material encounters.

\section{Researcher involvement}

In Sikes' (2008) tradition, I was conscious that I brought my knowledge and understanding about life, gained through my experiences of place, events, people and 
emotions, to the research. I did not set out to simply chronicle the stages I went through in the research nor sort or rearrange the narratives that I was privileged to elicit. Instead, I attempted to carefully craft the research narrative (Richardson, 1990), linking events and selecting sections of stories to focus on. I was conscious that I made these connections and selections as the human researcher that I am, embodied in time and space, alive. I did not speak for my participants, or make claims for constituencies to which I did not belong, for, as Richardson (1990) questions, why should I write somebody else's life?

I wrote up the research in the first person to remind the reader of my own involvement in the process. The "I", as Chase (2008) suggests, exposed my own narrative action in the research. It is the "I" who "re-present[ed]" (Sikes and Gale, 2006, Sikes, 2009) the stories through my interpretive lense, and the "I", as in research by Sikes (2008), served to declare my presence in the re-presentations and discussions.

Sikes (2008) emphasises that there is a vast difference between knowing about particular issues intellectually and living them experientially. Her own experiences of life, she acknowledges, affected her reactions to her research. In this research, too, I could not perceive the stories or react to them except from my involved, "intertwined" (Martin and Kamberelis, 2013, p.672) vantage point, in the world. The stories resonated more or less with me depending on the extent to which they correlated with my own experiences of being in the world. This assumes the "material feminist" (Lenz Taguchi, 2013, p.707) idea of people as made, formed, grown by the material world that envelops them. As an encultured being, then, cultivated in particular physical spaces, submerged by the waves of words, objects and sensations that envelope me, I felt more or less at home with the stories as a whole or different sections of them.

\section{A reflexive stance}

I write to learn, learn as I write, write what I feel, feel as I write. With Richardson (1990) I believe that narrative writing helps me to understand my own life. My own life story had a place in the research. In sections, I consciously wrote about my own childhood experiences, and, throughout the research process, I re-shaped my thoughts as I communicated new perspectives. I did not consider this human, emotive aspect of the writing to be an obstacle. As Richardson and St Pierre (2008) proposed, writing contains "both the limitations and the strength of human feelings" (p.480). I was limited by my understanding of 
the world, but my unique experiences and perceptions, mixed with my disposition to write, offer an opportunity to create something new, give a personal perspective, present my responses to the narratives.

I was not writing as an avatar, with no feelings, but as a living being in the world. Unlike a scientific paper in which "the findings reported are objective and uncontaminated by the heart" (Sandelowski, 1994, p.53), my own research was unashamedly heart-led, human, driven by my emotional and cognitive responses to people's lives. Writing also helped me to understand my past. In writing about my childhood, I was re-experiencing it anew and thereby connecting more immediately with the issues of the research.

My writing supported me to adopt a reflexive approach. Autobiographical sections served as examples of this writing-to-deepen-understanding approach. My own physical and emotional involvement in the writing, as articulated by Richardson and St Pierre (2008) moved me to feel more deeply. My feelings were important in the research in which I was suggesting that practitioners tap into their emotional understanding of the world as they develop 'landscapes of love' in their own work contexts. Feelings, I suggest, whether spoken or felt in the body, articulated in words or incorporated in people's ways of being, play an important part in developing professional approaches to love in the nursery. The subject of this research is thus mirrored in the form of it, just as the form mirrors the subject.

\section{Discussions about the research poems}

One of the participants, Flori, talked about the differences between being a mother and a practitioner. She said she reassured a parent when their child did not want to go home at the end of the day: "You're Mummy and you're always going to be Mummy." I encapsulated this part of the data in a poem. Richardson (1993) wrote a research poem about a woman's life in which she used "only her words" (p.696). Inspired by this piece, I wrote a poem about Flori's expressed longing to be a mother using words from her interview transcript. Like Richardson, I engaged in “writing 'data' as a poem” (p.696). So, although I decided to step away momentarily from academic prose, I wanted to remain "faithful" (p.696) to my understanding of what Flori said about not being a mother.

\section{Lets me be a mum \\ A childminder's refrain}

One of the reasons I chose childminding 
It lets me be a mum

I love it!

$$
\begin{aligned}
& \text { Playing } \\
& \text { Singing Joking }
\end{aligned}
$$

Lets me be a mum

I love them

As if I were the mother

Mother

I

Love - Equals - Feeling safe - Equals - "I trust you"

Every child is different

I love it!

Flori paused in her narrative when she spoke about her longing to be remembered in some way by the children she cared for. She broke down in tears when she said:

If I can leave on any of the thirty that I have had, that pass through here - If I could leave just a single thing, a song, words, in Spanish maybe, a situation, you know, a memory, then that's

it, I'm done - I'm done, that's more for me.

This section of this participant's transcript communicated her sense of loss when particular children moved away from her setting. It marked, as I perceived it, a deeply emotional moment within the narrative. Deep emotions such as these, I experience, are difficult to convey in prose. In this particular instance, I too was lost for words, and felt unable to capture my emotional response to the story. After a significant period I wrote a haiku ${ }^{1}$ to convey the pain I sensed this participant felt:

\section{No poem for pain}

Bare branches in winter

White blossoms bloom in springtime

And quickly go, Oh!

\footnotetext{
${ }^{1} \mathrm{~A}$ haiku is a short, Japanese poem consisting of three lines of five, seven and five syllables. A haiku usually makes reference to nature.
} 
I do not claim to match my participant's apparent pain in this haiku. The haiku, rather, helped me to make sense of her pain. The poem also helped me to make sense of and succinctly encapsulate the narrative. At the same time, I fully acknowledge that the poem may or may not be helpful for the reader.

Another of the participants, Kathleen, spoke very tenderly about her daily visits to her elderly mother, moving her hand as she spoke, as if she were stroking her. This participant's mother, as her narrative revealed, was her most faithful friend and ally during her painful school years. I was struck to learn about the mother's death when I returned to my participant on my second visit. I attempted to capture this image of love in my lyrical poem about this participant's story. A purely narrative approach, I felt, would be inadequate to this task.

\section{Demonstrative love}

(Kathleen's lyrical refrain)

Tell me you love me

Believe in me

Show me you love me

Touch me

Stroke nana's hand, son

Gently, soothing

Stroke nana's hand son

Sit with her awhile

Be kind to me

Include me

Tell me what I'm good at

Befriend me

Stroke nana's hand, son

Gently, soothing

Stroke nana's hand son

Sit with her awhile

Be part of my family

Age is no barrier

Open your doors

Embrace me

Stroke nana's hand, son

Gently, soothing 
These verses and refrains, embedded in the spiral-patterened research process served as vehicles for expressing my own emotions in response to my participants' narratives. The lyrical lines also more closely and respectfully, I sensed, matched the ambiguities, depths of feeling and silences within the stories, "privileging emotion and emotionality" (Leggo, 2008, p.15).

The poems I composed for the research were pieces of me, speaking. As the poet and playwright T.S. Eliot (1950) reflected, "the question of communication, of what the reader will get from it, is not paramount" (p.21). It is more important, he put forward, that each poem should feel right for the poet. If the reader accepts the poem, that is a bonus.

Another of my participants, Angela, expressed a real passion for nature and new life, and applied this passion to her role as a nursery teacher. She conveyed deep emotion, for example, in the way she spoke about a vulnerable chick at the nursery, through her facial expressions and emphases. Writing the poem helped me to communicate this more aptly, I suggest, than an explanation.

\section{Living moments \\ (Angela's refrains)}

Little chick, out of your shell

More vulnerable than the others

You want to live

Let me help you

Push, push your way through!

If you live and grow strong

I will feel all warm inside

Let me help you

And gently pull you into life

Fragile, vulnerable one

Seedlings, minibeasts

And all tiny creatures with a potential for life

Children

Come to this place 
To be nurtured slowly into life

I am like a midwife

Here to pull you through into life in the world

I can see you want to push your way through

I recognise that little spark of livingness in you

I will help you

You won't notice me helping you

To grow strong

You will experience it

The poem helped me to focus on the unique and personal aspects of the narrative in question. The participant's facial expressions and tone of voice made an impression on me as much the things that she said. Poetry, I felt, was a more fitting vessel for the emotional content of her interview narrative. Through writing the poem I arrived at the metaphor for working with young children as nurturing new plant and animal life. This helped me to perceive the work of early years practitioners in a different way. Alsup (2006) noted that metaphorical images sometimes lead to thoughts and feelings that might not have otherwise been arrived at. With reference to work by Gillis and Johnson (2002), I am also aware that my choice of metaphors may help me to understand my assumptions and beliefs about early years pedagogy. The poem includes the simile: "I am like a midwife". Gillis and Johnson provoked me to ask: Why do I associate the work of early years pedagogues with midwifery? What does this reveal about my beliefs and values?

I did not use poetry as an attempt "to close anything down" (Leggo, 2008, p.168). Instead, as Leggo (2008) put forward, poetry creates an opportunity to be "open to the world, open to process and mystery, open to fragmentariness...." (p.168). In the same vein, Rorty (1991) cautioned against adopting too much of a "cause and effect", "right and wrong" approach in any field, and "forget the possibility of poetry" (Rorty, p.45).

\section{Poetry in research}

I used poetry with a belief that both scholarly research and poetic expression can be combined and that aesthetic forms may be used to explore and communicate some aspects of the research (Neilsen, 2008, Leggo, 2008). Scholarly language alone can be "inadequate" (Neilsen. p.98). 
Neilsen (2008) proposed that language is a "blunt instrument" (Neilson 2008, p.101), and that poetry "draws upon nonrationalist ... ways of knowing" (p.101) to establish a different and resonating register. Using poetry, suggested Nielsen, is like "writing in a new key" (p.101). This research sits within Neilsen's "nonrationalist" (p.101) and Phipps and Saunders' "non-instrumental" (p.268) space. These propositions rest comfortably alongside my own open, "nonrationalist", post-modern (Richardson 1990), relativist (Rorty 1991) stance. I offered a few poems as part of the research to evoke rather than inform. The poems about my participants represent my distilled responses to their stories.

Sandelowski (1994) wrote about poetry and other art forms as sometimes "more true to life" (p.52) than traditional research articles. For Sandelowski, a line in a poem can sometimes provide a vision of human nature or resonate with the reader more than any conventional rendition of research. Sandelowski suggested that the arts, including poetry, may provide us with insights about people's lives that are "resonant" (p.52) with the audience's own experiences, or offer them a sense of recognition.

Poetry is also part of who I am as a person. My father recited poems to me when I was a child and wrote short poems for me when he lived abroad. I learned to appreciate rhyme and verse from a very young age. My father's own mother also wrote lyrics and poems. I come from a family who migrated from continent to continent for a variety of reasons. As a family, we learned to live apart from each other, and sometimes we used poetry to express our love for each other. I have also attended poetry workshops, set my own lyrics to my own musical compositions, listened to poetry for enjoyment, and read poetry out loud. Accordingly, I was drawn to this form of expression in my work. It seemed like the natural thing to do.

Additionally, poetry allowed me a means through which to present the data in a different way to stimulate renewed attention on the topic (Winterson, 1996, Phipps and Saunders, 2009, Lapum et al 2011). Lapum, Ruttonsha, Chursh, Yau and David (2011) used poetry to "disrupt the way [people] see, perceive, and understand ... the world around [them]" (p.112). The authors found that nurses who supported patients through open-heart surgery became quite accustomed to the technical practices and procedures of this work, and that the use of poetry in an exhibition would lead to a disruption of the usual ways of seeing things, "calling attention to these deeply entrenched routines" (p.102). I found this idea useful in my own research in which people talk about their practice in their ECEC settings, some of which might be quite habitual. I was also drawn to this idea of presenting things in a 
different form so that my interpretations of people's constructions of love in ECEC might stand out, or be perceived differently.

For the reader, poetry provided a break in the continuous prose. This was not only a break in a visual sense, with fewer words more sparsely laid out to view on the page, but also a break in activity. The poems served as an opportunity to for the researcher and reader to break from the academic discussion. Poems could serve instead as opportunities to stop, or "dwell momentarily" (Barone, 2001, p.25) within the discussions.

Despite my strong desire to promote poetry, however, I also believe that poetry in research should be carefully crafted, and that diligent efforts should be made to ensure that it is aesthetically pleasing. I concur with Sikes (2012) who warned of the dangers of presenting poor poetry as research. Such activities, she proposed, "do no service to their author or to the acceptance of them as legitimate forms of social science re-presentation" (p.572). Accordingly, I attended poetry workshops to develop my skills, and was careful to compose the poems "on the basis of data" (Sikes, 2012, p.571). As in work by Richardson (1993), I wrote some poems solely on extracts from the interview transcripts. Although I present only four poems in this article, I actually wrote several poems as part of the research process, and all of these helped me to think about the data.

I did not claim that the poems contained in the research necessarily demonstrated particular points or led to a thesis, since "poetry is not the product of reason" (Phipps and Saunders, 2009, p.367). Instead, through the poems, the reader is given the opportunity to make their own meaning from the research as a whole and be affected in different ways, or moved (Walsh 2012, p.276). Readers may be moved in an emotional sense or moved along in their understanding of the stories, or even moved into action in relation to future research.

\section{End notes}

In this paper I have argued that poetry within a slow, recursive, spiral-patterned methodology is appropriate for research about affective matters in people's lives. I have made reference to research about love in Early Childhood Education and Care and argued that poetry writing, as an aesthetic more than scholarly form of writing, is helpful to the process of making meaning. Poetry in academic papers offer readers opportunities to be struck, touched, affected differently. I have also proposed that the spiral-patterned 
methodological approach offers researchers time to reconsider the data, read more widely, gain new insights, be moved. This type of slow research also serves to represent participants' voices gently and justly, with time for them to think more deeply about what they say between visits, reflect on their work, explore issues associated with loving children. All involved on the spiral-patterned pathway, then, may engage in thinking on the topic over time, unhurriedly. Accordingly, this approach might be particularly beneficial for research about social injustices. Participants and researchers alike may gain courage to engage in creative representations to express the depths of their feelings.

At the still point of the turning world. Neither flesh nor fleshless;

Neither from nor towards; at the still point, there the dance is

'Burnt Norton' by T.S. Eliot, 1944 


\section{References}

Alsup, J. (2006). Teacher identity discourses: negotiating personal and professional spaces. Mahwah, New Jersey, U.S.A.: Lawrence Erlbaum Associates.

Bagley, C. \& Castro-Salazar, R. (2012). Critical arts-based research in education: performing undocumented historias. British Educational Research Journal, 38 (2), 239-260.

Barone, T. (2001). Science, art and the predispositions of educational researchers. Educational Researcher, 30 (7), 24-28. ISSN: 0013189X

Barrett, M.S. (2009). Sounding lives in and through music: a narrative inquiry of the 'everyday' musical engagement of a young child. Journal of Early Childhood Research, 7 (2), 115-134. DOI: http://dx.doi.org/10.1177/1476718X09102645

Bochner, A.P. (2014). Coming to narrative: a personal history of paradigm change in the human sciences. Walnut Creek, CA, USA: Left Coast Press.

Bourdieu, P. (1991). Language and symbolic power (G. Raymond \& M. Adamson Trans.). Cambridge, England: Polity Press.

Bourdieu, P. (1997). Pascalian meditations (R. Nice Trans.). Cambridge, England: Polity Press.

Braun, V. \& Clarke, V. (2006). Using thematic analysis in psychology. Qualitative Research in Psychology, 3 (2), 77-101. DOI: http://dx.doi.org/10.1191/1478088706qp063oa

Bruner, J. (1990). Acts of Meaning. Cambridge, Massachusetts: Harvard University Press.

Burr, V. (2003). Social Constructionism ( $2^{\text {nd }}$ Ed). Hove, England: Routledge.

Caine, V. \& Estefan, A. (2011). The experience of waiting: inquiry into the long-term relational responsibilities in narrative inquiry. Qualitative Inquiry. 17 (10), 965-971. DOI: http://dx.doi.org/10.1177/1077800411425152

Ceglowski, D. (2002). Research as Relationship. In N.K. Denzin \& Y.S. Lincoln. (Eds.), The Qualitative Inquiry Reader (pp. 5-24). London, England: Sage.

Chase, S.E. (2008). Narrative Inquiry: Multiple lenses, approaches, voices. In N.K. Denzin \& S.Y. Lincoln (Eds.), Collecting and Interpreting Qualitative Materials (pp. 57-94). London, England: Sage Publications.

Clandinin, D.J. \& Rosiek, J. (2007). Mapping a Landscape of Narrative Inquiry: Borderland Spaces and Tensions. In D.J. Clandinin. (Ed.), Handbook of Narrative Inquiry: Mapping a methodology. (pp. 35-75). Thousand Oaks, Calif. USA: Sage Publications. 
Clandinin, D.J. \& Connelly, F.M. (1996). Teachers' professional knowledge landscapes. Educational Research, 29 (3). 24-30.

de Carteret, P. (2008). Storytelling as research praxis, and conversations that enabled it to emerge. International Journal of Qualitative Studies in Education, 21 (3), 235-249. DOI: http://dx.doi.org/10.1080/09518390801998296

Deleuze, G. \& Guattari, F. (1988). A Thousand Plateaus: Capitalism and Schizophrenia. (B. Massumi Trans.). London, England: The Althone Press.

Deleuze, G. \& Guattari, F. (1994). What is philosophy? London, England: Verso.

Denzin, N.K. (2008). Interpretive Biography. In J.G. Knowles \& A.L. Cole. (Eds.), Handbook of the Arts in Qualitative Research (pp. 117-125). Los Angeles, CA, USA: Sage.

Denzin, N.K. (2010). Moments, mixed methods and paradigm dialogs. Qualitative Inquiry, 16 (6), 419-429. DOI: http://dx.doi.org/10.1177/1077800410364608

Denzin, N.K. (2011). The Politics of Evidence. In N.K. Denzin \& Y.S. Lincoln (Eds.). The Sage Handbook of Qualitative Research. $\left(4^{\text {th }}\right.$ Ed.) (pp. 645-657). Los Angeles, Calif., USA: Sage.

Elfer, P., Goldschmied, E. \& Selleck, D.Y. (2012). Key persons in the Early Years: building relationships for quality provision in early years settings and primary schools. $\left(2^{\text {nd }}\right.$ Ed.). Abingdon, England: Routledge.

Eliot, T.S. (1944) Four Quartets. London, England: Faber and Faber.

Eliot, T.S. (1950) Poetry and Drama. London, England: Faber and Faber.

Flick, U. (2009). An introduction to qualitative research. London, England: Sage.

Foucault, M. (1972). The archaeology of knowledge. (A.M. Sheridan Smith Trans.). London, England: Routledge Classics. (Original work published 1969).

Gillis, C. \& Johnson, C.L. (2002). Metaphor as renewal: re-imagining our professional selves. English Journal, July 2002.

Gergen, K.J. (1991). The saturated self: dilemmas of identity in contemporary life. U.S.A.: Basic Books.

Goldstein, L. (1997). Teaching with love: a feminist approach to early childhood education. U.S.A.: Peter Lang.

Goldstein, L. (1998). More thank gentle smiles and warm hugs: applying the ethic of care to early childhood education. Journal of Research in Childhood Education, 12 (2), 244-261. 
Halley, J. (2002). This I know: An exploration of remembering childhood and knowing now. In N.K. Denzin \& Y.S. Lincoln (Eds.), The Qualitative Inquiry Reader (pp. 91-103). London, England: Sage.

Huebner, D.E. (1999). Knowledge: An Instrument of Man, In V. Hillis. (Ed.), The lure of the transcendent: collected essays by Huebner (pp. 36-43). Mahwah, New Jersey, USA:

Lawrence Erlbaum Associates.

Hughes, J. (1997). Lines of Flight: Reading Deleuze with Hardy, Gissing, Conrad, Woolf. Sheffield, Sheffield Academic Press.

Jackson, A.Y. \& Mazzei, L.A. (2012). Thinking with theory in qualitative research. London, Routledge.

Lapum, J., Ruttonsha, P., Chursh, K., Yau, T. \& David, M.A. (2011). Employing the arts in research as an analytical tool and dissemination method: interpreting experience through the aesthetic. Qualitative Inquiry, 18 (1), 100-115. DOI:

http://dx.doi.org/10.1177/1077800411427852

Leggo, C. (2008). Astonishing silence. In J.G. Knowles \& A.L. Cole. (Eds.), Handbook of the arts in qualitative research (pp. 165-174). Los Angeles, Calif., USA: Sage.

Lenz Taguchi, H. (2013). Images of thinking in feminist materialisms: ontological divergences and the production of researcher subjectivities. International Journal of Qualitative Studies in Education, 26 (6), 706-716.

http://dx.doi.org/10.1080/09518398.2013.788759

Lewis, P. (2011). Storytelling as research/research as storytelling. Qualitative Inquiry, 17 (6), 505-510. http://qix.sagepub.com/context/17/6/505

Lynch, K., Baker, J. \& Lyons, M. (2009). Affective equality: love, care and injustice.

Basingstoke, England: Palgrave Macmillan.

Martin, A.D. \& Kamberelis, G. (2013). Mapping not tracing: qualitative educational research with political teeth. International Journal of Qualitative Studies in Education. 26 (6), 668679. http://dx.doi.org/10/1080/09518398.2013.788756

Oliver, C., Nesbit, S. \& Kelly, N. (2013). Dissolving dualisms: how two positivists engaged with non-positivist qualitative methodology. International Journal of Qualitative Methods. 12, University of Alberta.

Osgood, J. (2012). Narratives form the Nursery: Negotiating professional identities in early childhood. Abingdon, England: Routledge.

Neilsen, L. (2008). Lyric Inquiry. In J.G. Knowles \& A.L. Cole. (Eds.), Handbook of the Arts in Qualitative Research (pp. 93-102). Los Angeles, USA: Sage. 
Page, J. (2011). Do mothers want professional carers to love their babies? Journal of Early Childhood Research. 1 (14), 1-14. DOI: 10.1177/1476718X11407980

Page, J. (2013). Childcare choices and voices: using interpreted narratives and thematic meaning-making to analyse mothers' life histories. International Journal of Qualitative Studies in Education. http://dx.doi.org/10.1080/09518398.2013.805850

Phipps, A. \& Saunders, L. (2009). The sound of violets: the ethnographic potency of poetry? Ethnography \& Education, 4 (3) 357-387. ISSN: 1745-7823 Retrieved June 8, 2012 from: Education Research Complete, EBSCOhost.

Plummer, K. (2001). Documents of life 2: An invitation to a critical humanism. London, England: Sage Publications.

Pollner, M. \& Emerson, R.M. (2001). "Ethnomethodology and Ethnography” In P. Atkinson, A. Coffey, S. Delamont, J. Lofland \& L. Lofland. (Eds.), Handbook of Ethnography. Los Angeles, Calif., U.S.A.: Sage Publications.

Richardson, L. (1990). Writing Strategies: Reaching diverse audiences. Newbury Park, USA: Sage Publications.

Richardson, L. (1993). Poetics, dramatics, and transgressive validity: the case of the skipped line. The Sociological Quarterly, 34 (4) 695-710. Downloaded from 143.162.2.135 on Sun, 27 Apr 2014

Richardson, L. \& St. Pierre, E.A. (2008). Writing - A method of inquiry. In U. Flick. (Ed.), An introduction to qualitative Research (pp.?-?). London, England: Sage.

Rorty, R. (1982). Consequences of pragmatism. Minneapolis, MN, USA: University of Minnesota Press.

Rorty, R. (1986). Foucault and epistemology. In D.C. Hoy, Foucault: a critical reader. (pp. 41-50). Oxford, England: Basil Blackwell.

Rorty, R. (1991). Essays on Heidegger and others: philosophical papers. Volume 2.

Cambridge, England: Cambridge University Press.

St Pierre, E.A. (2011). Post Qualitative Research. In N.K. Denzin \& Y.S. Lincoln (Eds.). The Sage Handbook of Qualitative Research. ( $4^{\text {th }}$ Ed.) (pp. 611-624). Los Angeles, Calif., USA: Sage.

St Pierre, E.A. (2013) The posts continue: becoming. International Journal of Qualitative Studies in Education, 26 (6), 645-657. http://dx.doi.org/10.1080/09518398.2013..788754

Sandelowski, M. (1994). The proof is in the pottery: toward a poetic for qualitative inquiry. In J.M. Morse. (Ed.), Critical Issues in Qualitative Research Methods (pp. 46-63). London, England: Sage. 
Sikes, P. \& Gale, K. (2006). Narrative approaches to education research. University of Plymouth http://www.edu.plymouth.ac.uk/RESINED/narrative/narrativehome.htm

Sikes, P. (2008). At the eye of the storm: an academic'(s) experience of moral panic. Qualitative Inquiry, 14 (2), 235-253. DOI: http://dx.doi.org/10.1177/1077800407309407

Sikes, P. (2009). The study of teachers' lives and careers: an auto/biographical life history of the genre. In J. Satterthwaite, H. Piper \& P. Sikes. (Eds.), Power in the academy (pp. 169183). Stoke on Trent, England: Trentham Books.

Taggart, B., Sylva, K., Melhuish, E., Sammons, P. \& Siraj, I. (2015) Effective pre-school, primary and secondary education project (EPPSE 3-16+): how pre-school influences children and young people's development outcomes over time-Research brief. Department for Education, www.gov.uk/government/publications

Walsh, S. (2012). Contemplation, artful writing: research with internationally educated female teacher. Qualitative Inquiry, 18 (3), 273-285. DOI:

http://dx.doi.org/10.1177/1077800411431553

Williams, R. (1976). Keywords: a vocabulary of culture and society. London, England: Fontana Press.

Winterson, J. (1996). Art Objects: Essays on Ecstasy and Effrontery. London, England: Vintage. 